\title{
Action of gentian violet on Mucosus capsulatus group.
}

\section{By J. G. Fitzergerald and Gertrode Mackintosh.}

\section{[From the Hearst Laboratory of Pathology and Bacteriology, University of California.]}

It has recently been shown by Churchman ${ }^{1}$ in two interesting communications bearing on the subject that the aniline dye, gentian violet, has a selective bactericidal action on certain bacteria. The action of the dye has been spoken of as bacteriostatic, indicating that the growth of some species of bacteria is inhibited. In addition to this inhibiting influence, Churchman believes the substance has also a very definite bactericidal action. It was shown in the publications referred to that the action of gentian violet as a bacteriostatic or bactericidal agent presented in a general way a parallelism with the Gram stain. The majority of gram positive bacteria are inhibited by gentian violet, while the majority of gram negative bacteria are not. The action of gentian violet can be observed on the divided plates or by staining with gentian violet and determining subsequently whether the microörganisms so treated will grow on culture media. On divided plates, one half of an ordinary petri dish is covered with plain nutrient agar, the other half with nutrient agar to which has been added an aqueous solution of gentian violet; such a plate when streaked with gram positive bacteria will show a growth only on the side of the plate where there is no gentian violet, while gram negative bacteria usually grow equally well on the plain agar and on gentian violet agar.

Since it seemed possible that the differentiation of closely related species might be accomplished by the use of divided gentian violet plates, the method has been used in a further study of the Mucosus capsulatus group. In all, thirty-six strains of bacteria have been investigated; they include $B$. ozana, $B$. lactis aerogenes, $B$. enteriditis, $B$. pneumonice Friedlander, B. rhinoscleromatis, B. capsulatus, and B. Mucosus capsulatus. All of the

1 Churchman, Journal Experimental Medicine, Vol. XVI, No. 2, August, I9r2, pp. 22I-247, and Vol. XVI, No. 6, December, I9I2, pp. 822-830. 
thirty-six were found to be gram negative. This is in harmony with most of the observations heretofore recorded, although a contrary statement is made with reference to $B$. rhinoscleromatis by McFarland ${ }^{1}$ and by Page. ${ }^{2}$ When studied by means of the gentian violet agar plates, twenty-nine of the thirty-six cultures were found to grow equally well on plain agar and on gentian violet agar. Seven others, however, behaved differently. No growth could be obtained on the gentian violet agar side of the divided plates. Churchman has mentioned the fact that certain bacteria when stained will not grow on one culture medium but might grow on a more selective medium. The seven strains that refused to grow on ordinary gentian violet agar were then planted on serum agar violet, and three of them grew on serum agar violet, although they had refused to grow on ordinary violet agar. The other four did not grow even on the more favorable medium and behaved in the same way as most of the gram positive bacteria. Thinking the substitution of a selective culture medium for ordinary medium in the case of certain of the gram positive bacteria might result in a change in the action of gentian violet on their growth, $B$. diphtherice and streptococcus were planted on serum agar violet plates, and on agar violet plates. Both plates failed to show a growth on the violet side.

Of the three microörganisms that grew on serum agar violet, two have remained constant, growing well on serum agar violet but not at all on ordinary agar violet; the third one, however, has shown a very interesting adaptation. The culture is one of $B$. pneumonia Friedlander from the Kral collection. This bacillus when grown on a plate containing serum violet and agar violet can be induced to grow on agar violet once it has started to grow on serum violet; if, however, the growth is started from the opposite side of the plate on plain agar, it cannot be made to grow on violet agar. The experiment was made by putting in one plate culture, serum agar, serum agar violet, agar violet, and plain agar, the different media merging into one another in a petri dish. The behavior of the microörganism is thus shown to be inconstant toward gentian violet, depending on the culture media on which

${ }^{1}$ McFarland, "Pathogenic Bacteria and rotozoa," 7th edition, I9I2, p. 785.

2 Page, Journal Medical Research, Vol. XXVI, No. 3, July, I9I2, pp. 489-499. 
it is grown, that is, a microörganism incapable of growing in the presence of gentian violet readily does so on a more suitable medium, and it can adapt itself to a less suitable medium if started on a selective medium. Gentian violet has not been found to be of any value in the differentiation of the Mucosus capsulatus group. Further; the microörganisms of this group which refuse to grow on agar violet are representatives of what we at present regard as three distinct species.

It would seem from the result of the experiment here recorded that while the action of gentian violet on bacteria is usually constant, it is sometimes susceptible of modification and may not be as fundamental a characteristic as originally supposed.

\section{7 (793)}

On the influence of light on the electric potential of bacterial and other suspensions.

By S. W. Young (by invitation).

[Laboratory of Physical Chemistry, Stanford University, Cal.]

Experiments in this laboratory have shown that light and other forms of radiant energy exert a marked influence on the rate of wandering in the electric current. Thus the rate of wandering of arsenic sulphide suspensions is about twice as great in the dark as under strong illumination in the sun, or in the carbon arc or in the Nernst lamp. On the other hand, the rate of wandering of mastic emulsions is increased under strong illumination, and that to the extent of about forty per cent. of the value in the dark. Ferric hydroxide is retarded in the light to the extent of about six per cent., while chlorophyll suspensions are accelerated in the light to the extent of about forty per cent. The effect of the radiant energy is not in general instantaneous, but requires a few minutes exposure to reach its greatest value. In general also the effect is reversible, that is colloids whose rates of wandering have been influenced by radiant energy, return to their original values if kept in the dark for some minutes.

These phenomena are very interesting in connection with photochemical reactions in general. Arsenic sulphide suspensions 